\title{
RADEN NGABEHI JASADIPURA I, COURT POET OF SURAKARTA: His Life and Works
}

\author{
Soebardi
}

Within Javanese courtly and prijaji circles of the nineteenth and early twentieth centuries, Jasadipura's works became very popular and as a consequence were subjected to constant rewriting and reinterpretation. They were regarded for their didactic and religious importance, as well as their literary value. Despite this and although Jasadipura was the court poet of Surakarta under first Paku Buwana III (1749-1788 A.D.) and then Paku Buwana IV (1788-1820 A.D.), information about his life is quite limited. Dutch sources for the period deal mainly with the rise of Dutch power in Java and contain no account of Jasadipura. The writings of Jasadipura himself provide no details about his life.

C. F. Winter, a Dutch scholar of Javanese literature, resided in Surakarta during the lifetime of Jasadipura's son, Jasadipura II, 1 but his book Javaansche Zamenspraken (Javanese Conversations) is confined to a discussion of the works written during the period--those of Jasadipura $I$ as well as his son.

The sole source of information specifically concerning Jasadipura's life is a book published in 1939, in modern Javanese but written in Javanese script, by three authors--R. Sastrasumarta, R. Sastrawaluja and R. Ng. Jasapuraja--on behalf of the Committee of the Descendants of Jasadipura $I$. The authors themselves were all his descendants. The book, entitled Kitab Tus Padjang (Book on the Descendant of Padjang, i.e., Jasadipura I), was published simultaneously with the 200 th anniversary of the founding of the Surakarta palace. ${ }^{2}$ The Committee felt this an appropriate mark of their respect for Jasadipura who, during his lifetime, had experienced the transfer of the Mataram capital from Kartasura to Sala (Surakarta, or Solo). Jasadipura had afterward served as poet of the court in its new locale until his death.

The Tus Padjang traces Jasadipura's genealogy back to Sultan Adiwidjaja (Djaka Tingkir, C. 1568-1586 A.D.), the first king of Padjang, and also recounts the type of education he received and

1. Th. Pigeaud, Literature of Java (The Hague: Nijhoff, 1967), I, p. 237 .

2. R. Sastrasumarta, R. Sastrawaluja and R. Ng. Jasapuraja, Kitab Tus Padjang, Kawedalaken awit namaning komite Jasadipuran I (Surakarta: Budi Utama, 1939). 
his later role as court poet. According to this account, Jasadipura was the son of Raden Tumenggung Arja Padmanagara, a Bupati/Djaksa ${ }^{3}$ of Pengging, the center of an old kingdom west of Surakarta, during the reign of Paku Buwana I (1704-1719 A.D.). He was born in Pengging on Friday Pahing, in the month Sapar, second month of the Muslim calendar, in the year Djim-akhir, eighth year of the Windu-cycle ( 1654 Anno Javanico, or 1729 A.D.). When he was a child, he was called Bagus Bandjar, and nicknamed Djaka Subuh, because he was born at subuh (daybreak). ${ }^{4}$ When he was eight years old, he was taken to Kedu to study Islam and mysticism with a kjai called Anggamaja. He showed even at this early age an extraordinary ability in the study of religion and literature.

At the age of fourteen, having finished his studies, he entered the service of the King of Kartasura, Paku Buwana II (1726-1749 A.D.). The kingdom was then convulsed by a Chinese rebellion, and that period, from 1740 to 1743 , is since popularly known as Djaman Geger Patjina ("period of the Chinese revolt"). Paku Buwana II was forced to flee from Kartasura eastward to Kenteng in the Panaraga area. The rebels occupied Kartasura and installed Raden Mas Garendi, still a minor, as king with the title Sinuhun Kuning. ${ }^{5}$ His reign was brief, however, for Paku Buwana II secured active Dutch support, in return for large concessions to the East India Company. On October 3 , 1743 , Sinuhun Kuning was forced to surrender and was exiled to Ceylon.

Bagus Bandjar meanwhile had been promoted to a member of the King's life guard. ${ }^{6}$ He was given the name Kudapangawe, and was responsible for bearing the ancestral weapon called Kjai Tjakra. During this period he gained a deep knowledge of Javanese ethics and customs.

After Paku Buwana II re-occupied Kartasura, Bagus Bandjar was appointed to a position more in keeping with his literary talents, that of secretary to the King, under the direction of Prince Widjil. His skill at composition was such that he earned the title Pudjangga Taruna, "young court poet."

Because the palace at Kartasura suffered damage and was regarded as a place now magically dangerous to Paku Buwana II, it

3. The title for a chief judiciary official during the Kartasura period.

4. Tus Padjang, P. 9 .

5. Raden Mas Garendi was the son of Bupati Tepasana, who was the son of Sunan Mas, that is Amangkurat III (1703-1708 A.D.).

6. In Javanese the position is known as pradjurit nameng djadja, "soldier shielding the chest." Tus Padjang, p. 15. 
was decided to move the capital to Sala, east of Kartasura. According to the Tus Padjang, Bagus Bandjar, by then already known as Raden Ngabehi Jasadipura I, played an important role in the transfer of the capital.' The marshy area around Sala had presented building problems, but in the course of meditation, Jasadipura received a flash of insight and saw how the swamps could be drained and the new palace constructed. After Paku Buwana II moved his capital, in 1670 A.J. (1745/46 A.D.), Jasadipura changed his residence to the village of Kedungkol, today known as Jasadipuran (residence of Jasadipura), in the district of Pasar Kliwon, Surakarta.

Jasadipura had thus witnessed the major political events causing the decline of Kartasura; perhaps he even bore arms in the Chinese war. He watched the growing impotence of Mataram, the spread of the Company's power and the confusion caused by the Mangkubumi war. In 1755, a peace-treaty was signed between the Dutch East India Company and Mangkubumi in Gijanti, whereby the kingdom of Mataram was divided into two equal parts ${ }^{8}$ with Surakarta, the older kingdom, for Paku Buwana III and Jogjakarta, the newer kingdom, for Mangkubumi who took the title Hamengku Buwana I.

After the signing of this treaty, Surakarta appeared to come to life. It entered a period of gradually increasing order and tranquility; the kingdom was consolidated; the damage left in the wake of the struggle of several years before was repaired. At the same time, there was a marked revival in Javanese cultural Iife. Great efforts were made to produce new works on Javanese literature and to replace books which had been destroyed or had disappeared during the Chinese rebellion and the Mangkubumi war.

Jasadipuna, in his capacity as court poet, had the task of restoring and reviving the wealth of old Javanese literature. In the course of this work, he successfully re-wrote several old Javanese books presenting them with unusual skill in a poetical form characteristic of Modern Javanese. As well, Jasadipura directed much attention to Islamic works and also to history. His historical studies provide valuable information about the kingdom during the eighteenth century. Having seen the destruction of war, he undoubtedly wanted to preserve records of past glory.

As well as a founder of literature in early surakarta, Jasadipura was also a person of considerable political skill. He won the confidence of Paku Buwana IV, who once asked him to become his Minister; Jasadipura refused because of his already

7. Tus Padjang, PP. 26-9.

8. The Javanese expression for this is sinigar semangka, which can be rendered literally as "to be divided as a watermelon." 
advanced age. He died in Surakarta on the twentieth day of the month Zulkaidah, the eleventh month of the Muslim calendar, in the year Wawu, the seventh year of the Windu-cycle (1729 A.J., March 14, 1803). He was buried in Pengging, and his grave has become a holy place which is still honored.

After his death, Jasadipura's position as court poet was taken by his son who adopted the name $\mathrm{R}$. Ng. Jasadipura II. As a youth, Jasadipura II had been called R. Padjangwasita and later, when appointed a bupati, the grand name of Raden Tumenggung Sastranagara. He had a son called R. Padjangswara, later known as R. T. Sastranagara II, who was the father of Bagus Burham, court poet of Surakarta in the latter part of the nineteenth century under the name of $\mathrm{R}$. Ng. Ranggawarsita. The latter wrote a great number of books on Javanese ethics and history and is known as the Pudjangga Panutup, "last court poet," of the Surakarta Kingdom.9

Jasadipura left a legacy of books which are still popular. His language exercised a tremendous influence on the development of the Javanese language in Surakarta, which became the standard for present-day Javanese. Jasadipura was a prolific and manysided writer; he may be studied equally as a poet, historian, religious teacher and mystic--although these various fields are not necessarily as disparate to a Javanese as they might appear to a European.

Perhaps most important are his representations of the masterpieces of Old Javanese literature. The greatest and best of these is the Serat Rama, an adaptation of the Ramayana Kakawin, ${ }^{10}$ written between 898 and 910 A.D., ${ }^{11}$ during the reign

9. Serat Babad Tjarijos lampahanipun suwargi Raden Ngabehi Ranggawarsita, Pudjangga Ageng ing Nagari Surakarta Adiningrat, Kawedalaken dening Komite Ranggawarsitan (Surakarta: 1931), I, PP. I-4.

10. R. M. Ng. Poerbatjaraka dan Tardjan Hadidjaja, Kepustakaan Djawa (Djakarta: Djambatan, 1957), pp. 2-5. See also: N. J. Krom, Hindoe-Javaansche Geschiedenis, second ed. (The Hague: Nijhoff, 1931), PP. $135 \mathrm{ff}$; and Berg, Inleiding tot de studie van het Oud-Javaansch (De Bliksem, 1928), pp. 51-4.

11. Poerbatjaraka, Kepustakaan Djawa, p. 2. Kern believes that the old Javanese Rämäyana dates from the beginning of the thirteenth century; Brandes places it in the tenth, while Stutterheim maintains that the Rämāyana Kakawin originates from the first half of the Kadiri period (cf. Berg, Inleiding, p. 53). Poerbatjaraka's view is based on his examination of the language in the available manuscripts compared with inscriptions in stone and copper found in Java. Poerbatjaraka, 
of King Dyah Balitung in central and east Java. Written in old Javanese verse, the language is of such beauty that Poerbatjaraka says: "Never before in my life have I read a Javanese book which equals the language of Ramáyana."12 Many scholars have studied it because of its importance in Javanese and Balinese society, as a book representing high religious, moral and philosophical ideals. ${ }^{3}$ Undoubtedly, it was this inherent importance which stimulated Jasadipura to rewrite it in Modern Javanese verse. 14 It was later published, in Javanese script by C. F. Winter, accompanied by an introduction in Dutch containing a brief outline of the contents. ${ }^{15}$ Van Dorp also printed it in

"De dateering van het Oud Javaansche Rāmāyana," Gedenkschrift 75 jarig bestaan van het Koninklijk Instituut voor Taal-, Land-en Volkenkunde van Nederlandsche-Indie (The Hague, 1926).

12. Poerbatjaraka, Kepustakaan Djawa, P. 4.

13. In particular see Stutterheim, Räma legenden und Rāma reliefs in Indonesien (München: Müller, 1925); and Poerbatjaraka, "De dateering."

The Rāmayana Kakawin has been published in Old Javanese by $\mathrm{H}$. Kenn ('s-Gravenhage, 1900). He has also translated six cantos into Dutch in his Verspreide Geschriften ('sGravenhage: Nijhoff, 1929), X, p. 79 ff. This was later continued by $H$. H. Juynboll after 1922 in the Bijdragen. Juynboll has also compiled a Kawi-Balineesch-Nederlandsch Glossarium based on the Old Javanese Rāmāyana ('sGravenhage: Nijhoff, 1902). Poerbatjaraka translated the Kakawin into Indonesian, but, to my knowledge, it has not been published. See also C. Hooykaas, The Old Javanese Rämäyana Kakawin, with a special reference to the problem of interpolation in Kakawins, Verhandelingen van het Koninklijk Instituut voor de Taal-, Land-en Volkenkunde, XVI (1955).

14. Various manuscripts of the Serat Rama are listed in Juynboll, Supplement op den Catalogus van de Javaansche en Madoereesche Handschriften der Leidsche Universiteits-Bibliotheek (Leiden: E. J. Brill, 1907-1911), II, pP. 61-4. Jasadipura's manuscript is listed under No. CMXIX (Cod. 4). Other Serat Rama Manuscripts are described in A. C. Vreede, Catalogus van de Javaansche en Madoereesche Handschriften der Leidsche Universiteits-Bibliotheek (Leiden: E. J. Brill, 1892), pp. $6-9,389,390$. Cf. Pigeaud, Literature of Java, I, P. 240 and II, P. 26. Comment on the accuracy of Jasadipura's work is found in Poerbatjaraka, Kepustakaan Djawa, p. 152 and on the insertion of new elements, ibid., p. 153 .

15. Verhandelingen van het Bataviaasch Genootschap van Kunsten en Wetenschappen, XXI/2. 
Javanese script in 1875 and 1884. In 1925, Balai Pustaka published it in Roman script with an introduction by J. Kats.

Another major work of Jasadipura is the Serat Bratajuda, an adaptation of the old Javanese work, Bhäratajuddha Kakawin, written by Mpu Sedah in 1157 A.D. during the reign of King Djajabhaja (1135-1157 A.D.) of Kadiri. Mpu Sedah did not finish his work because according to tradition, he fell into disgrace and was sentenced to death. The task of completing it fell to Mpu Panuluh. ${ }^{16}$ The main theme is the struggle between the Pandawas (descendants of Pandu) and the Kaurawas (descendants of Kuru), both of whom were descended from Bharata; its origin is the Sanskrit epic Mahābhärata. The Serat Bratajuda was written in matjapat verse by Jasadipura on the command of Paku Buwana III and perhaps later re-edited by Jasadipura II. It has been published in Javanese script by Dr. A. B. Cohen Stuart. 17

A third work, the Ardjuna Wiwaha, is an adaptation of the Ardjuna Wiwăha Kakawin, written by Mpu Kanwa during the reign of King Airlangga (1019-1042 A.D.).18 For the Javanese, this work is important not only for its literary value, but even more for its ethical and philosophical content. It is regarded as an allegory of Man's struggle against evil to achieve perfection. The popularity of the story in present-day Javanese society is mainly attributable to the version of Jasadipura; the various modern Javanese versions all derive from his.

Jasadipura's Ardjuna Wiwaha was published by Dr. W. Palmer van den Broek in 1868. In addition to Jasadipura's work, Paku Buwana III also adapted a version of the work; this has been

16. Concerning the Bhäratajuddha see Berg, Inleiding, pp. 49-50; Poerbatjaraka, Kepustakaan Djawa, pp. 24-5; and the introduction by Cohen Stuart in Verhandelingen Bataviaasch Genootschap, XXVII (1860), pP. i-IxV.

17. Verhandelingen Bataviaasch Genootschap, XXVII, XXVIII (1860). For a description of the various manuscripts see Vreede, Catalogus, PP. 9-12 and Juynboll, Supplement, II, p.6. Cf. Pigeaud, Literature of Java, II, $\mathrm{pP}$. 713-14, 740 . A resume of the contents of the Serat Bratajuda is contained in Pratelan kawontenaning boekoe-boekoe (1920), I, Pp. 64-65.

18. The Ardjuna Wiwăha Kakawin was first published in Javanese script by R. Friederich in Verhandelingen Bataviaasch Genootschap, XXIII $(1850)$. Later Poerbatjaraka published it in Roman script accompanied by a Dutch translation in Bijdragen, LXXXII (1926); see also Berg, "De Arjuna Wiwāha, Erlangga's levensloop en bruiloftslied?" Bijdragen, XCVII (1938) and his Inleiding, p. 49. Cf. Poerbatjaraka, Kepustakaan Djawa, PP. I6-7. 
published by J. F $C$. Gericke in Javanese script with an introduction in Dutch. ${ }^{9}$ Recently, Dr. A. Seno Sastroamidjojo published a philosophical interpretation of the Ardjuna Wiwaha in Indonesian. Seno's book attracted wide interest especially from members of the mystical organizations which have flourished in Java since World War II. ${ }^{20}$

Yet another of Jasadipura's works is an adaptation of the Dewarutji.21 No Old Javanese version of this text has yet been found, 22 although Professor Poerbatjaraka has discovered a version in Middle Javanese. ${ }^{3}$ Poerbatjaraka's text, judging by its language and prosody, probably came from the period when the Islam first entered Java, about the beginning of the sixteenth century A.D. This text provides important material for comparison with other versions, in order to ascertain which is the oldest of the many manuscripts known. This text, which is not in lakon form, belongs to the group of original versions and resembles only slightly the prose text, Nawarutji, published by Prijohoetomo, no doubt because of changes and admixtures which the latter underwent in Bali.24 Nevertheless, the kernel of the Nawarutji shows that it must have had the same origin as Poerbatjaraka's text.

19. Verhandelingen Bataviaasch Genootschap; XX (1844). Various manuscripts of the Ardjuna Wiwāha, or Mintaraga, are listed in Juynboll, Supplement, II, pp. 9-10 and Vreede, Catalogus, PP. 1-3. Cf. Pigeaud, Literature of Java, I, P. 241 and II, P. 48 .

20. A. Seno Sastroamidjojo, Sekelumit unsur filosofik tjeritera Ardjuna Wiwaha (Djakarta: Kinta, 1963). Another Indonesian adaptation which should be mentioned is that of Sanusi Pane (Djakarta: Balai Pustaka, 1940). The Paku Buwana III version has been published in Indonesian by the Language Branch of the Cultural Bureau of Jogjakarta: Kitab Ardjuna Wiwaha: Tjerita wajang jang mengandung pendidikan, Disadur dan di Indonesiakan oleh Tjabang Bagian Bahasa, Djawatan Kebudajaan K.P.P. \& K. (Jogjakarta, 1959).

21. A brief description of the various manuscripts is found in Juynboll, Supplement, II, Pp. 8-9 and in Vreede, Catalogus, PP. 248-52. Cf. Pigeaud, Literature of Java, II, P. 30 .

22. Prijohoetomo, Nawaruci (Groningen: J. B. Wolters, 1934), P. 140 .

23. Poerbatjaraka published the text with a Dutch translation in Djawa (1940), pp. 11-28.

24. Ibid., p. 31 . 
A short fragment of Jasadipura's Dewarutji is found in the book Pesinden Bedaja which contains the date 1724 A.J. (1796 A.D. $)^{25}$ and is one of the oldest versions in matjapat.

How does Jasadipura's Dewarutji compare with Poerbatjaraka's text? Poerbatjaraka's text, omitting introductory episodes, begins with Bhima's journey to the ocean in search of the sacred water of life, as directed by his teacher Drona. Jasadipura begins by describing how Bhima studied with Drona and was ordered by him to search for the water of life. Bhima then set out for Amarta, the home of his brother, King Judistira, to take leave of him and tell him of his quest. Jasadipura either worked from oral tradition, or as seems to be indicated in the Serat Tjabolek, from a Kawi version better and more complete than Poerbatjaraka's, but which has not yet been rediscovered.

In all, there are four groups of extant versions of the Dewarutji story. Poerbatjaraka's version, written in Middle Javanese using 01d Javanese prosody, belongs to the first group and must be distinguished from the texts in tembang gede meter (great verse, Old Javanese prosody), but written in Modern Javanese. One of these latter has been published by Prijohoetomo under the title of Bimasutji. ${ }^{26}$ The second group contains the version in prose form, written in Middle Javanese, known as the Nawarutji. ${ }^{23}$

To the third group belongs the version of Jasadipura, written in Modern Javanese in matjapat. It was retold by Kramaprawira of Madiun and printed in Javanese script by Van Drop in 1870,1873 and 1880 , and was republished in Javanese script by Tan Khoen Swie in Kediri in 1922 and 1929. This edition includes a colophon by Mangunwidjaja which interprets the mystical import of the work. Tan Khoen Swie's edition includes an interpolation of eight stanzas which do not occur in Kramaprawira's edition. ${ }^{8}$ In 1956, R. Brotokesowo in Jogjakarta also rewrote the Serat Dewarutji based on Jasadipura's version.

The fourth group includes a number of prose versions. $R$. Tanojo's work was published in Modern Javanese using Roman script. Another, based on Jasadipura's text but in Indonesian,

25. Poerbatjaraka, Kepustakaan Djawa, p. 164.

26. Prijohoetomo's text consists of 24 cantos accompanied by a summary in Dutch. It was published in his Nawaruci, Pp. $140-207$.

27. Ibid. Published together with a Dutch translation.

28. Tan Khoen Swie, Serat Dewa Rutji, 5th edition, pp. 35-7. The interpolation starts from "Badan djaba wudjud kita iki" on p. 35 and ends with "luwih gengnja kalepasan iki" on p. 37. 
was published together with an introduction by the Language Branch of the Cultural Bureau in Jogjakarta. ${ }^{29}$

Seno Sastroamidjojo has made a study concerning the mystical contents of the Dewarutji and its importance. ${ }^{30}$ There has also appeared an earlier interpretation by Siswoharsojo. ${ }^{3}$

Jasadipura also adapted the classical work Serat Panitisastra, which is based on the Niticastra Kakawin (Book on Right Conduct). ${ }^{32}$ Vishnuite in character, it contains instructions concerning the wisdom of life and right conduct as moral guides for people from different walks of life--kings, priests, warriors, parents and children, men and women--in carrying out their individual obligations towards God and their fellow men. Man must live with modesty, humility, generosity, love for truth, justice, righteousness and wisdom, but life also involves danger and enemies. Jasadipura's adaptation, completed in $1725 \mathrm{~A} . \mathrm{J}$. ( 1798 A.D.), is written in Kawi miring (lit. sloping Kawi) ${ }^{3}$ with sekar ageng meter. 34

29. R. Tanojo, Bima Sutji, disadur dan di Indonesiakan (Solo: Sadubudi, 1953); Kitab Dewarutji, di sadur dan di Indonesiakan oleh Tjabang Bagian Bahasa, Djawatan Kebudajaan Kementerian P.P. \& K. (Jogjakarta, 1958).

30. Seno Sastroamidjojo, Tjeritera Dewa Rutji dengan arti filsafatnja (Djakarta: Kinta, 1962).

31. Ki Siswoharsojo, Wedaran Serat Dewaroetji (Jogjakarta, 1953). For a more recent study see: A. H. Johns, "From Buddhism to Islam: an Interpretation of the Javanese Literature of the Transition," Comparative Studies in Society and History, IX/I (1967), Pp. 40-50. Further discussion of the ethical and mystical teachings of the Dewarutji are contained in Soebardi, "The Book of Cabolek" (Ph.D. Thesis, Australian National University, 1967), I, pp. 148-67.

32. Poerbatjaraka has edited this in Roman script with a Dutch translation and introduction, published in the Bibliotheca Javanica (an occasional publication of the Bataviaasch Genootschap van Kunsten en Wetenschappen), IV (1933). Raffles also refers to the Nitiçastra Kakawin in his History of Java (London: Black, Parbury and Allen, 1817), I, p. 390, where he quotes a part of the text with an English translation. See also Poerbatjaraka, Kepustakaan Djawa, PP. 48-51.

33. See Vreede, Catalogus, p. 263 , No. 3.

34. In addition to Jasadipura's adaptation there are others: the Panitisastra Kawi-djarwa, written in 1735 A.J. (1808 A.D.) cited in Vreede, Catalogus, p. 263 , No. 5. The contents of the manuscript appear very similar to those of cod. 87 (18) 
Jasadipura also worked on stories of Islamic origin, including the Menak, the Tadjusalatin and the Ambija. ${ }^{35}$ The Menak story appeared in Java at least as early as the time of Sultan Agung of Mataram (1613-1645 A.D.). It originated from the Romance of Amir Hamzah, a Malay Islamic work famous during the sixteenth century. ${ }^{36}$ The Malay version itself derives from a Persian tale, of the same name. ${ }^{37}$ The stories are based on a historical figure, Amir Hamzah, a Muslim hero and an uncle of

in Juynboll, Supplement, II, P. 86, where it is noted that the author is Jasadipura II. This version was translated by Dr. D. L. Mounier in 1843 together with a preface and notes and published in the Tijdschrift voor Nederlandsche-Indië, $\mathrm{L} / 2$.

Another Panitisastra Djarwa was written in matjapat by Jasadipura II in 1746 A.J. (I8I9 A.D.), see Vreede, Catalogus, p. 263 , No. 3 .

A prose adaptation was done by Raden Pandji Puspawilaga in 1770 A.J. (1842 A.D.). See Vreede, Catalogus, p. 263, No. 7. Poerbatjaraka gives a different date in "Nìticāstra Kakawin," p. 6 .

35. Menak literally means "noble, illustrious." Amir Hamzah, the principal character, is known as wong menak or wong agung menak, "a noble, illustrious man, a hero." Later the word menak became the name of the story rather than Amir Hamzah. Tadjusalatin, from the Arabic Tadju's-Salatina, means "the crown of kings." In Malay the work is known as Mahkota Segala Radja-Radja. Ambija is from Arabic Anbiya, and is plural form of $\mathrm{Nabi}$ or prophet.

36. The Malay Hikayat Amir Hamzah, is mentioned in the Malay Annals. According to the Annals, one night when the army commanders and their troops were on guard defending Malacca from attack by d'Albuquerque, they asked Sultan Ahmad for a book of battle stories to read, the Hikayat Muhammad

Hanafijah. The Sultan gave them the Hikayat Amir Hamzah instead, believing it enough that his warriors be as brave as Amir Hamzah. But the soldiers rejected the book. See, T. D. Situmorang and A. Teeuw, eds., Sedjarah Melaju (Djakarta: Djambatan, 1952), pp. 297-8; also C. C. Brown, "Malay Annals," Journal Royal Asiatic Society, Malayan Branch, XXV, pts. $2 / 3(1952)$, p. 168 .

37. A critical study of its origins and the relation of the Malay version to the Javanese and Sundanese Menak has been made by $\mathrm{Dr}$. Ph. S. van Ronkel, De Roman van Amir Hamzah (Leiden: E. J. Brill, 1895). See also, R. 0. Winstedt, "A History of Classical Malay Literature," JRASMB, XXXI, pt. 3 $(1958)$, pp. $80-1$. 
the Prophet Muhammad, who in the Menak is known as Wong Agung Menak. ${ }^{38}$

From the beginning of its development, the Amir Hamzah story has undergone interpolations of new tales gathered from the local scene and changes of names and roles of the characters. Many widely differing versions of the Romance have developed in various regional languages. ${ }^{39}$

The version of the Serat Menak widely known in Java developed from the adaptation by Jasadipura. He based his work on a version written in $1715 \mathrm{~A} . \mathrm{D}$. by Narawita at the command of the consort of Paku Buwana I. 40 The Menak stories are divided into ten parts, each of which has the name of the principal figure or the most important place in the section. ${ }^{4}$

Jasadipura's Serat Menak was first published by C. F. Winter in 1854 in an incomplete edition. Later, in early 1923, Van Dorp, in Semarang, published a seven-volume edition in Javanese script, based on manuscripts of a matjapat version by Raden Pandji Djajasubrata. Between 1933 and 1941, Balai Pustaka printed the Menak stories in Javanese script, based on Jasadipura's text, in forty-six volumes.

The Serat Tadjusalatin ${ }^{2}$ is a free adaptation of a Malay work, the Mahkota Segala Radja-Radja, written in 1603 A.D. in

38. A resume of the Kitab Menak appears in Vreede, Catalogus, pp. 36-60. Cf. Pigeaud, Literature of Java, II, PP. 25, 245 .

39. The Menak stories have become even more popular since they were incorporated into the repertoire of the wajang golek puppet plays.

Pigeaud has written a short article about the way in which the story of Amir Hamzah was adapted to the mythological and cosmological system of the Javanese; "The Romance of Amir Hamzah in Java," Bingkisan Budi (Leiden: W. Stijthoff, 1950), pp. 235-40.

40. Poerbatjaraka, Kepustakaan Djawa, p. 123. For a description of the manuscripts available see "Menak" by R. M. Ng. Dr. Poerbatjaraka in Beschrijving der Javaanse Handschriften (Bandung: Bataviaasch Genootschap van Kunsten en Wetenschappen, 1940).

41. Van Ronkel, De Roman van Amir Hamzah.

42. Various manuscripts in Javanese have been described in Vreede, Catalogus, pp. 297-303 and in Juynboll, Supplement, II, pp. $\overline{126-7 \text {. Several Malay version manuscripts are also }}$ described in Juynboll, Catalogus, pp. 213-6. 
Atjeh by Bukhari from Djohor. ${ }^{43}$ Derived from a Persian work, it outlines the responsibilities of kings, high officials of the kingdom, and the common people. It also includes ilmu firasat (physiognomy) which later became popular in sumatran and Javarese, as well as among Malay, court circles. ${ }^{4}$ This was, in all probability, the reason Jasadipura decided to adapt it into Modern Javanese verse. ${ }^{45}$ It was printed in Javanese script by Van Dorp in 1873 and 1875 and also by Rusche in Surakarta in 1922.46 A comparison of the Javanese and Malay versions has been made by Dr. Gunning and Roorda van Eysinga. ${ }^{47}$

Jasadipura also adapted the legends of the prophets whose names are mentioned in the Kuran. It opens with the Creation, succeeded by stories about Adam, Idris (Enoch), Noah, Hud ('Eber), Salih and others. In Modern Javanese, this book is known as Kitab Ambija (Malay: Anbia, Ar. Anbiya', prophets) and also as Tapel Adam.48 One manuscript under the latter title was published by Lange and Company of Batavia in 1859.

43. The Malay version was first published in 1827 A.D. by Roorda van Eysinga; it also contained a Dutch translation. Professor Hooykaas summarized the contents of the Mahkota Segala Radja-Radja in his book Over Maleise Literatuur (Leiden: E. J.Brill, 1947), pp. 167-73; see also his Perintis Sastra (Djakarta: J. B. Wolters, 1951), PP. 146-7; and van Ronkel, "De Kroon der Koningen," Tijdschrift Bataviaasch Genootschap, XLI, PP. 55-69.

44. According to tradition, Abdullah bin Abdul Kadir Munsji, a Malay teacher, journalist and writer of the early nineteenth century, studied the chapter on physiognomy in order to learn Raffles' characteristics. Hooykaas, Perintis Sastra, p. 147 .

45. Two dates have been suggested for Jasadipura's adaptation: one, 1247 A.H. (1759 A.D.) during the reign of Paku Buwana III; the second, 1139 A.H. (1727 A.D.). The first is more likely as Jasadipura's presumed birth date was not until 1729 A.D. See Vreede, Catalogus, P. 298.

46. Poerbatjaraka, Kepustakaan Djawa, p. 170 .

47. Vreede, Catalogus, PP. 298-301.

48. A description of the Javanese manuscripts is found in Vreede, Catalogus, pp. 23-6 and Juynboll, Supplement, II, pp. 35-40. It is also called Tapel Adam because the beginning tells how Adam's form, or tapel, was made from a mixture of various kinds of clay. Tapel undoubtedly derives from the Arabic tafl, tafal meaning infancy, or childhood, and also potter's clay. 
A brief summary of the contents of the Tapel Adam is found in the Pratelan." It differs from the Malay Kitab Anbia; for example, the Arab authorities quoted in the Malay version are omitted in the Tapel Adam and various isnad (chains of transmitters) àlso do not occur in the Javanese version. These differences have been studied in detail by Gerth van Wijk. ${ }^{50}$ There is yet another manuscript containing stories about prophets which is entitled Tapsir Ambija (Exposition on the Prophets) written in 1233 A.H. (1817 A.D.) which displays an obvious resemblance to the 1859 version of the Tape ${ }^{\text {Adam. }}{ }^{51}$ According to Professor Poerbatjaraka, the extant manuscript of Jasadipura's adaptation dates from 1731 A.J. (1804 A.D.), 52 but this could not be the original one, since Jasadipura died in 1803 A.D.

Jasadipura also wrote the Babad Gijanti. It was composed in matjapat during the reign of Paku Buwana III. ${ }^{3}$ As he indicates in the opening stanzas, Jasadipura wanted to write a history of the kingdom, beginning with the transfer of the kraton from Kartasura to Surakarta, and using the kraton documents which were available. ${ }^{54}$ He commences with an introductory story about Paku Buwana II, which, according to Jasadipura, is quoted from the Babad Kartasura. It relates his installation

49. Pratelan, I, pp. 75-84.

50. A brief description of the Malay version is found in van Ronkel, Catalogus, Pp. 212-6. See also: Gerth van Wijk, "De Koranische Verhalen in het Maleisch," Tijdschrift

Batavaasch Genootschap, XXXV, PP. 253, 326-45; XXXVI, pP. $650-99$.

51. Mellema, "De Schepping van Adam volgens Javaans-Moslimse Traditie," in Bingkisan Budi, p. 196.

52. Poerbatjaraka, Kepustakaan Djawa, p. 169.

53. Gijanti is the name of a place on the slopes of Mt. Lawu, now part of the Mangkunagaran region ten miles east of Surakarta. The peace treaty between the VOC and Pangeran Mangkubumi was signed here on February 13, 1755. C. Poensen, "Mangkubumi," Bijdragen, 6th series, LII, p. 240.

A description of several manuscripts of the Babad Gijanti is contained in Juynboll, supplement, II, pp. 96-7. Cf. Pigeaud, Literature of Java, II, p. 720. A brief examination of the connections between the Babad Gijanti and the Babad Tanah Djawi as historical texts is found in Hoesein Djajadiningrat, Critische Beschouwing van de Sadjarah Banten (Haarlem, 1913), pp. 202-3. See also Poensen, "Mangkubumi," pp. 223 ff.

54. Serat Babad Surakarta (Jogjakarta: Budi Utomo, 1916), I, canto 1 , stanzas 2 and 3 . 
as King of Kartasura, how he faced the attack from the Chinese rebels and then fled to Panaraga to return later after the rebels had been driven out with the help of the company. It ends with preparations for the transfer of the Kartasura capital.

After the introductory episode, the Babad Gijanti describes in detail the important events after the founding of surakarta, especially the war between Prince Mangkubumi and Mas Said on one side, and the King of Surakarta, backed by the Dutch East India Company on the other. This war, essentially a struggle against the evergrowing power of the Company, lasted from 1746 until 1755, and ended with the division of the Kingdom of Mataram.

Part of Jasadipura's manuscript of the Babad Gijanti was first printed, under a double title Babad Gijanti and Babad Surakarta, by A. Buning of Jogjakarta in four volumes, successively in the years $1885,1886,1888$ and 1892. Another edition under the double title was published, also in four volumes, by N. V. Budi Utomo of Surakarta. ${ }^{55}$ A comparison of this edition with that printed by A. Buning, shows that both contain the same material, apart from one episode which is longer in the Buning than that in the Budi Utomo version. Between 1937 and 1939, Balai Pustaka published the complete Babad Gijanti in Javanese script in twenty-one slim volumes, supplemented with maps and an index.

The last work of Jasadipura to be discussed here is the Book of Tjabolek, composed towand the end of the eighteenth century. ${ }^{56}$ There are extant eleven manuscripts, of varying length, and one printed version, published by Van Dorp in 1885 . From a comparison of these, it is clear that regardless of individual differences, all have a common core, all, ultimately, derive from a single source. The basic story consists of three sections.

The first relates the story of Hadji Amad Mutamakin, a religious teacher from the village of Tjabolek in the Tuban district. He was arraigned before the royal tribunal of Kartasura, then under the jurisdiction of Paku Buwana II. The theologians of the region, led by Ketib Anom Kudus, had accused Amad Mutamakin of violating Islamic law by devoting himself to ilmu

55. A summary of the Babad Gijanti published by Buning appears in Pratelan, II, Pp. 5-28. The version published by $N$. V . Budi Utomo was entitled, Serat Babad Surakarta ingkang katelah dipun-wastani Babad Gijanti mawi sekar matjapat The Babad Surakarta which has become known as Babad Gijanti written in matjapat verse].

56. A critical edition of the text accompanied by an introduction, English translation with notes and variae Lectiones is contained in Soebardi, "The Book of Cabolek." 
tekad (the science of union with God). At first it seemed that Hadji Mutamakin would certainly be sentenced to death by burning, as had been the fate of Sjech Siti Djenan (from Giri), Sunan Panggung (from Demak), Sjech Among Raga (from Mataram) and others who taught and propagated similar heterodox mystical doctrine. In this event, however, the Hadji from Tjabolek was pardoned because the king decided that he had kept his esoteric beliefs to himself and had not preached to society at large. The section demonstrates the courage and skill of Ketib Anom Kudus during the exchange of opinions ensuing from his stand against the doctrine expounded by Hadji Mutamakin. Section two contains the episode of the Dewarutji story, beginning with Bhima plunging into the mighty sea to search for the water of life and his meeting with a tiny God named Dewarutji, from whom he receives the doctrine on the Perfection of Life. The third section is an interpretation of the teaching of Dewarutji by Ketib Anom Kudus.

The differences and discrepancies among the versions represent liberties taken by copyists in adapting the story, inserting episodes from other works according to their own taste, interests and convictions. Many of the manuscripts contain the Mangkubumi episode describing the ascetic life of the Mataram aristocrat; this no doubt represents a desire on the copyist's part to glorify Mangkubumi, as the founder of the Kingdom of Jogjakarta. But such an interpolation affects the character of the story, by adding a political purpose alongside the primarily religious motif of the work.

Not that all interpolations have such significance. Some may be intended by the copyist to indicate the scope of his own knowledge, and stem from sheer vanity. The different versions of the text of the Book of Tjabolek suggest that the popularity of the book during the end of the eighteenth and nineteenth century was considerable. The various versions reflect preoccupations of different times and places.

The Book of Tjabolek has attracted the attention of several scholars of Javanese culture. Professor C. C. Berg remarks that the Serat Tjabolek contains an important illustration of religious syncretism in Java. Professor Poerbatjaraka, in the introduction to his edition of a Dewarutji text, also mentions the Book of Tjabolek, and notes that the story of Dewarutji may well have become well-known among and loved among the Javanese, as a result of the exposition of its doctrine in the Book of Tjabolek. Professor P. J. Zoetmulder, in his study of Javanese suluk literature, quotes a number of passages from this story to illustrate his discussion of Javanese mysticism. Likewise, Dr. R. A. Rinkes, in writing about Sunan Panggung, also refers to the Book of Tjabolek, particularly the episodes of Sjech Siti Djenar, Sunan Panggung, Ki Bagdad and Sjech Among Raga, all four of whom, according to Javanese tradition, were condemned 
to death for heresy. ${ }^{57}$

Jasadipura was court poet of a kingdom which, since the beginning. of the eighteenth century, had experienced decline, fragmentation and, finally, collapse of its political power. The kingdom underwent an ever-deepening Dutch penetration aimed at complete domination of the island of Java. Consecutive treaties in $1705,1733,1743,1749$ and 1755 A.D. bound the Javanese kings hand and foot and constituted clear and saddening proof of the continuing expansion of Dutch economic and political power. ${ }^{58}$ For the kings of Java, especially Paku Buwana I, Amangkurat IV and Paku Buwana II, extension of the Company's power was unavoidable because it stemmed from their own weakness. Rivalry and conflict occurred within the royal families as all struggled for control of the throne. In each conflict, Dutch power played an important role, intervening to help one of the pretenders and, if necessary, annihilating or exiling his enemies. In return for Dutch help, the victor had to make territorial and economic concessions.

Paku Buwana II, who ruled in Mataram during Jasadipura's boyhood, was a very weak king who lacked individuality and who left important state affairs to the guidance of the Dutch. ${ }^{59}$ In $1743 \mathrm{~A} . \mathrm{D}$., he was installed as Susuhunan at Kartasura with the help of the Dutch who, subsequently, demanded a high price for their assistance. The kingdom of Mataram was divested of northern coastal areas considered important by the Dutch Company and, in consequence, lost its international trading connections and was isolated from the outside world. The kingdom became impoverished, compelled as it was to meet the cost of previous Dutch military operations.

57. C. C. Berg, "Indonesia," in H. A. R. Gibb, ed., Whither Islam? a Survey of Modern Movements in the Moslem World (London, 1932), p. 255; Poerbatjaraka, "Dewa Roetji," p. 8; P. J. Zoetmulder, Pantheisme en Monisme in de Javaansche Soeloek-Litteratuur (Nijmegen: J. J. Berkhout, 1935), Pp. 216-21, 289-90,312; D. A. Rinkes, "De Heiligen van Java," Tijdschrift Bataviaasch Genootschap, LIV, Pp. 138, 170-4.

58. For the text of these treaties see: de Jonge, De Opkomst van het Nederlandsch Gezag in Oost-Indië ('s Gravenhage: Nijhoff, 1875); 1705 treaty, V, PP. 261-8; 1733 treaty, VI, PP. 200-7; 1743 treaty, VI, PP. 434-47; 1749 treaty, VII, pp. 159-60; 1755 treaty, VII, PP. 298-303. Also Bustaman Soekanto, Sekitar Jogjakarta 1755-1825 (Djakarta: Mahabarata, 1952), pp. 178-81, 182-7.

59. A description of the character of Paku Buwana II is contained in Poensen, "Mangkubumi," PP. 224-6. 
Towards the end of his reign, Paku Buwana II experienced considerable opposition from Raden Mas Said, the son of Pangeran Adipati Mangkunagara (an older step-brother of Paku Buwana II), who had been exiled to Ceylon in 1730 A.D., and from Prince Mangkubumi who had not yet received the land promised to him for his service in quelling Mas Said's revolt. Paku Buwana II had left the question of the land grant to the discretion of the Dutch.6 The combined opposition of Prince Mangkubumi and R. M. Said brought chaos to Mataram and imposed a heavy burden on both the Dutch Company and the Javanese people. A state of turmoil prevailed when Paku Buwana II died in 1749 A.D. Several days before his death, he was forced to sign an agreement which surrendered sovereignty over Mataram to the Company and which acknowledged Paku Buwana III as his legal successor. ${ }^{1}$ Thus, Paku Buwana III became king under Dutch auspices.

Mangkubumi continued his opposition to the Dutch and Paku Buwana III and only made peace with the Dutch in 1755 A.D. after dissension arose between R. M. Said and himself. In the Treaty of Gijanti the remaining territory of Mataram was divided in two. The western region, which subsequently was known as Jogjakarta Adiningrat, became the domain of Prince Mangkubumi who now took the name Hamengku Buwana $I$. The eastern region became the realm of Paku Buwana III and, subsequently, was known as Surakarta Adiningrat. A further division of this region had to be made in 1757 A.D. when R. M. Said made peace with the Dutch and secured the region of Mangkunegaran which he ruled under the title of Pangeran Mangkunagara $I$.

At the beginning of the seventeenth century, Mataram had been the sovereign power in Java; by the latter half of the eighteenth century, it had become an utterly powerless Dutch vassal. Only in this period of total collapse did peace come to the kingdoms of Surakarta and Jogjakarta.

In Surakarta, which was now fragmented and clearly without political power, peace and tranquility prevailed. Under these conditions, $\mathrm{R}$. $\mathrm{Ng}$. Jasadipura I played his role as court poet. In view of the prevailing circumstances, it seems that he had little alternative other than to direct all his efforts toward defending and reviving elements of the old court culture, saving it from further collapse. He focused his attention on the glories of Javanese kingdoms in past ages and consciously promoted contemporary Javanese traditions which had their origins

60. See ibid., Pp. 233-5, for a balanced account of Prince Mangkubumi's motives in leading the 1746 revolt against Paku Buwana II and the Company.

61. De Jonge, De Opkomst, contains a detailed discussion of the transfer to the Company and the death of Paku Buwana II, esp. VII, pp. 156 ff. 
in the illustrious past. He revived, in Modern Javanese, many important old Javanese works and literary forms, for example, his adaptations of the Rāmäyana, Bhāratajuddha, Nitiçastra and Dewarutji which portray values originating in the Hindu-Buddhist religion of Java. Through the medium of Modern Javanese, the continuity of Old Javanese Hindu-Buddhist traditions has been ensured, because it can be presented easily both to court circles and to the population at large.

Jasadipura's adaptation of the old Javanese epic Rāmāyana into beautiful Modern Javanese poetic form as the Serat Rama proved the esteem in which the work was held as an important source of moral and philosophical tenets which formed the basis of Javanese court society and subsequently for the population in general. Jasadipura's work was literary as well as educational and played an important role in shaping the Javanese literature of that period.

Because of its instructional content, the most popular and widely known portion of the Serat Rama among present-day Javanese is Rama's advice to Wibisana who is ordered to succeed his deceased brother Dasamuka (Rawana) as king of Ngalengka. It outlines the eight principal qualities that a king should possess. Known popularly as Asta Brata (the Eight Virtues), they are associated with eight gods of the Hindu pantheon: unlimited beneficence with Indra; ability to repress all evil with Jama; persuasiveness and wise conduct with the sun-god, Surja; lovingness with Tjandra; keen awareness and deep insight with Baju; generosity with Kuwera; determination and cautiousness with Baruna; and courage and fierceness against any enemy with Brama. ${ }^{62}$ A section of the Serat Rama is also called Asta Brata but it contains Rama's instructions given to his stepbrother Bharata, when Bharata meets him in exile in order to relinquish the throne of Ayodhya to Rama as a sign of loyalty. Rama refuses and asks Bharata to become king of Ayodhya in his name. He advises Bharata on the responsibilities of a king, emphasizing that it is his duty, in carrying out the administration of the state, to promote peace, justice and prosperity for his subjects. ${ }^{63}$

Perhaps these instructions were intended to counteract the uncertainty and a presumed decline in moral values of the

62. An English translation of the Asta Brata is contained in Appendix III, of Soemarsaid Moertono, State and Statecraft in Old Java (Ithaca, N.Y.: Connell Modern Indonesia Project, 1968); see also pp. 43-4.

63. The section containing the Asta Brata originated from the third sarga (chapter) of the old Javanese Ramāyana Kakawin. An English translation by Soetjipto Wirjosuparto complete with notes was published as Astabrata, the Eightfold Teachings of Rama to Bharata (Djakarta, 1964). 
Javanese court. This, in my opinion, is not an unlikely possibility given the Javanese social tradition. Paku Buwana IV himself wrote a book called Wulang Reh (Teachings on Right Conduct) which contains wedjangen (instructions) concerning social morality and manners based on the examples of the royal ancestors, beginning with Panembahan Senapati, the founder of Mataram, to Paku Buwana IV. The Wulang Reh instructions are also directed at the ignorance of youth in all levels of Javanese society and warn them to seek out teachers who really do possess deep knowledge and prestige. The work observes that there are many people who are known as teachers, but whose knowledge cannot be trusted. 64

Similar writings appeared at the end of the nineteenth century, principal amongst them being the work of $\mathrm{R}$. $\mathrm{Ng}$. Ranggawarsita titledKalatida (The Age of Darkness). This work contains a satire on Javanese society of that period, which was marked by moral decline. The following nine-line stanza from the Kalatida is still widely quoted in present-day Indonesia to satirize conditions of Indonesian society in time of crisis:

[We] have witnessed a time of madness

in which everyone is confused in his mind

one cannot bear to join in the madness.

But if he does not do so

he will not share in the spoils

and will starve as a result.

Indeed it is the will of Allah

that those who are careful and vigilant

are much happier than those who are careless. ${ }^{6}$

The works of Jasadipura were not original works but rather adaptations accompanied by additions or deletions according to

64. Wulang Reh Winardi, by Paku Buwana IV with explanations by Reshi Wahono (Surakarta: Wahono, 1953), esp. canto I

(Dandanggula), stanzas 4 and 7 .

65. The Javanese text reads as follows (the transliteration is mine):

"Amehangi djaman edan

ewuh aja ing pambudi

milu edan nora tahan.

Jen $\tan$ milu anglakoni

boja kaduman melik

kaliren wekasanipun.

Dilalah karsa Allah

begdja-begdjane kang lali

luwih begdja kang eling lawan waspada."

From Andaran Kalatida Ranggawarsitan by Brotokesowo (Surabaja: Pustaka Nasional, 1950), stanza 7 (sinom meter). 
his own inclinations. Nevertheless, they contained an important and probably fitting message for his time. They were written in beautiful poetic form which, subsequently, greatly influenced the development of the Surakarta dialect and hence the Javanese language of today.

The Babad Gijanti, Jasadipura's historical work, illustrates the Javanese point of view concerning events in eighteenth-century surakarta. A full assessment of this work must await further investigation comparing it with other contemporary historical sources. Several scholars assert that the Babad Gijanti was written from the narrow standpoint of Surakarta, since Jasadipura was brought up within the circle of the surakarta court. ${ }^{6}$ Probably he did write it on the orders of the king, but careful reading reveals that, in describing events, Jasadipura gives many illustrations which, in my own view, were intended to emphasize the heroism of Prince Mangkubumi and his followers and the justice of his aspirations to the throne.

In fact, the hero of the Babad Gijanti is Prince Mangkubumi, who assumed the title of Pangeran Adipati Sukawati Senapatining Prang Pramuka Djajeng Rat, ${ }^{6} 7$ and later became the first ruler of Jogjakarta. On the other hand, Paku Buwana II, the king of Mataram, is portrayed as an extremely weak ruler, lacking personality, who resigned all affairs of state to the guidance of the Company.

The essence of the Dewarutji story is the instructions of the god Dewarutji to Bhima concerning perfection of life as the highest aim of human endeavor. "The Perfection of Life" is the aim of a mystic's life, formulated as pamoring kawula gusti ("the union between servant and the lord"). Dewarutji's teaching explains the relationship of Man to God, to the phenomenal world and to his own self and also endeavors to explain the ultimate goal of man's earthly existence and how he may achieve it. This mystical goal, is also known as weruh sangkan - paraning dumadi ("to know the whence and whither of creation").

In the Dewarutji, the Divine Essence is called Hjang Suksma (the Exalted Soul) and is the origin of all that exists on earth, the supreme essence of all that is. It gives life to all things. Nothing except Hjang Suksma exists of its own volition. Man and the visible world are manifestations of this Divine Essence. Its manifestation in man is the Pramana (the Material Soul), "the cause of particular life" whereas Hjang Suksma itself is

66. Djajadiningrat, Critische Beschouwing, p. 203, and also Poensen, "Mangkubumi," p. 235.

67. In English: "The crown prince of Sukawati, the Commanderin-Chief of the army, the most eminent and victorious in the world." 
the "source of life." The Pramana resides in man's body but is not subject to the sensations such as sadness, happiness, hunger and thirst which are experienced by the body. In fact, the Pramana is an individuation of the Divine Essence. It is said that God and man are one, just as an object and its reflection in a mirror are one. The one who looks into the mirror is Hjang suksma and its reflection in the mirror is the man. The task for the Javanese mystic is the attainment of gnosis of this unity by earnest endeavor and the highest spiritual discipline. Once man has achieved ultimate knowledge of the Unity of Man and God, according to the Dewarutji, this mystical awareness must be concealed from others. One who has achieved such awareness must be constantly alert and abjure all the dangerous qualities of pride and arrogance.

Through Jasadipura's effort, the Book of Dewarutji in Modern Javanese formed the basis for the revival of the ancient Javanese concepts of life which spread initially in the elite circle of the court and then to the group of prijaji outside it.

Jasadipura's efforts to demonstrate the importance of the Dewarutji world-view as the mainstay of spiritual life for the Javanese may be seen in his serat Tjabolek. This document portrays the tensions in Javanese religious life resulting after contact with Islam. The principal tension is between the ulama (Islamic scholars), the defenders of the sjariah (Islamic law), and those who rejected legalistic religion and professed Javanese mysticism. The conflict is a familiar theme in the Javanese traditions, such as in the stories of Sjech Siti Djenar, Sunan Panggung, and Sjech Among Raga of the Serat Tjentini.

In the Book of Tjabolek, Jasadipura shows a tendency to align himself with those ulama who regarded the sjariah as an exterior guide for Javanese religious life. Outwardly, he encouraged a life which emphasized the sjariah but for the spiritual life, he proposed that a Javanese in search of perfection should have as a guiding principle, teachings such as those of the Dewarutji, which in my opinion, explains why the Dewarutji story is afforded prominence in the Book of Tjabolek.

Jasadipuna's attıtude to the sjariah must be understood in the context of Javanese tradition. For Jasadipura the sjariah was merely a cover or wadah (container) which remained outside his system of belief and was not its essence. ${ }^{6}{ }^{8}$ From the

68. For the discussion of the sjariah as a wadah see especially Serat Tjentini, I-II, canto 41 , stanzas 26 and 27 . Sjech Among Raga advises Tambang Raras that the sarengat and tarikat are the container of everything (wadah sakalir) whereas hakekat and makripat are the seeds of the Gift (widji nugraha). If the seed is not deposited in a good container, certainly the Gift will not prosper. He wishes 
traditional point of view, changing the wadah by professing oneself a Muslim, presented no obstacle provided that the person concerned maintained his belief in Pamoring Kawula Gusti.

In other words, Jasadipura by adopting conciliation and aligning himself with Islamic legalism, which constituted a reality that the court must consider, hoped to preserve Javanese identity. The clothes would be Islamic, but the man beneath them would remain Javanese. As court poet, Jasadipura was perhaps extremely aware of the increasing decline in the power of the Surakarta kingdom. Consequently, the reassertion of Javanese cultural tradition became his main preoccupation, but he had to take account of the growing influence of Islam outside the court.

The syncretistic kraton-centered religious outlook which Jasadipura represented continued and, in an unusual way, flourished within the Javanese aristocracy and later within the newly-emerging prijaji circles. It became the mainstream of Javanese religious life but had to face the increasing challenge of Muslim orthodoxy during the nineteenth century. This challenge, though continuous and at times a source of tension between the two different religious traditions, failed to result in a decisive victory for the orthodox faction.

man to be ever vigilant, calm and not arrogant because of his mystical knowledge. The sjariah must be adhered to firmly and never abandoned. 